\title{
Macroergonomic intervention for work design improvement and raw materials waste reduction in a small footwear components company in Rio Grande do Sul-Brazil ${ }^{1}$
}

\author{
Renata Cornelli ${ }^{\mathrm{a} *}$ and Lia Buarque de Macedo Guimarães ${ }^{\mathrm{b}}$ \\ ${ }_{a, b}$ Graduate Program in Industrial Engineering, Federal University of Rio Grande do Sul, Av. Osvaldo Aranha 99 \\ $5^{\circ}$ andar, Porto Alegre, RS, 90035-190, Brazil, E-mail: liabmg@gmail.com
}

\begin{abstract}
This article presents a macroergonomic intervention carried out in a small footwear components company located in the state of Rio Grande do Sul, Brazil. The company's demand was related to the waste of the expensive raw-material (thermoplastic polyurethane or TPU) used to manufacture the components (high heels pegs). According to the managerial staff, the waste was workers responsibility due to the craft characteristic of the process. A participative method was used to evaluate the problems, propose and implement solutions, as well as evaluate their impact on the workers and the Company. Improvements in the work conditions resulted in increase of workers' satisfaction with the work and in $31.5 \%$ waste reduction.
\end{abstract}

Keywords: participative ergonomics, waste, footwear, components.

\section{Introduction}

The Industrial Revolution is the landmark of the substitution of the craft system by new production models (i.e., Fordism, Toyotism, Volvism) when manual tools and the guild production organization model were replaced by machines and manufacturing in large scale. Although industrialization generated job opportunities and a variety of products to fulfill needs and wants of a growing population, it impacts "...on the natural resource base of civilization through the entire cycle of raw materials exploration and extraction, transformation into products, energy consumption, waste generation, and the use and disposal of products by consumers. These impacts may be positive, enhancing the quality of a resource or extending its uses. Or they may be negative, as a re- sult of process and product pollution and of depletion or degradation of resources" [4].

Fordism, which started in the beginning of the 20th century in the USA aims to producing a maximum in a minimum amount of time, product quality being solely evaluated by sampling a few items in large batches of products. Defects were not a concern since large amounts of low quality products were sold at low price. The human costs involved were also not a concern since there was unskilled workforce to accept low wages to work in a fragmented, poor work system that is physically and mentally harmful [7,11-12]. This system was the benchmark until 1960-1970 when was replaced by Toyotism. The Japanese Toyota Production System (TPS) [1920], also known as Lean production, besides work organization changes in relation to Fordism (e.g. sub-

*Corresponding autor. E-mail:rcornelli@produção.ufrgs.br tel: +55 (51) 3308-3948 fax: +55 (51) 3308-4007 
stitution of the linear system with an unskilled worker fixed in one workstation by a cellular model composed by trained workers) defends the idea that any waste is a production loss and therefore, a cost, and should be eliminated in order to add more value to a product and make it more competitive in the market. Ohno [20] defined seven wastes to be eliminated: Transportation, Inventory (in the form of raw materials, work-in-progress -WIP or finished goods), Motion, Waiting, Over-processing, Over-production and Defects. As in Fordism, Lean production does not take into account the human or ergonomic costs, on the contrary, the system is know to exhaust the workers up to death (known as karoshi or death from over work) [14]. Also, the wastes do not consider the environment, since at the time the system was developed there was no awareness of the negative environmental impact of production systems that do not consider the conscious use of raw materials and/or cleaner and safer processes. Only in the 1990's the Japanese Committee for Design for Environment (DfE) has forced the Japanese companies to consider environmental issues in their processes and products [18].

Volvism, as applied from 1970 to 1990 in the Volvo's plants at Kalmar and Udevalla, Sweden, was developed considering ergonomics [5] but also did not take environmental issues into account. Work organization in the so-called socio-technical model was done by semi-autonomous teams in charge of the quality of both production and product. The plants were designed to avoid material handling and the adoption of awkward postures.

Although international awareness of the impact of industrial development goes back to the 1970's [2123 ], the early 1990's is the landmark of the environmental consciousness. Many laws in many countries (e.g. Resource Conservation and Recovery Act of 1976 [8], in the USA; Brazilian Environmental Law 6938 in 1981 [3]; Consolidated versions of the Treaty on European Union [9]) forced the companies to start adjusting their processes and products, by reducing waste generation, residuals or effluents during the production process or treating them before disposal. In Brazil, most companies attempt to comply with legislation not eliminating residuals at source but treating them at the end of the process. This type of solution, known as end-of-pipe, is not efficient since it uses resources to treat something that should not be generated. Residuals can be seen as resources or rawmaterials that did not end up as a product, are often toxic and a risk to both human and environment health and safety, and are a cost for the company since do not generate profit. Considering that residuals and effluents treatment is often pricy, they are a waste for the production chain [1].

The companies often hire external consultants to help them comply with legislation and do not take advantage of their internal human resources that probably know more about their own company's problems. Both ergonomic and environmental problems should be analyzed under a broader, more systemic approach, since the outcomes at the end of the process are just a reflexion of problems in the process as a whole.

This article presents an eight months study for work design improvement and raw materials waste reduction in a small footwear components company in the town of Campo Bom, state of Rio Grande do Sul, Brazil. The company understood that the high costs involved in the waste of the expensive rawmaterial (thermoplastic polyurethane or TPU) used in the manufacturing of the components (high heels pegs) were a result of lack of skills of the workers, since manufacturing was more of a craft than mass production. Participative ergonomics was used to highlight the problems and propose solutions for improving the system.

\section{Method}

Work analysis was done based on the participatory method Macroergonomic Work Analysis (MA) [15], which identifies the problems from the point of view of both workers and ergonomists, in order to propose and implement solutions for system's improvements.

MA comprises the same stages of most ergonomic methods: 1) appraisal; 2) diagnosis; 3) proposal of solutions; and 4) validation, adding a stage zero (named intervention launching) and gates between each stage in order to engage workers and managerial staff in the intervention process.

The study followed stages 0 to 3 during an eight months period, from May to December 2009. At the end of the project, after implementation of some proposals, stage 4 assessed the outcomes of the intervention.

\subsection{Stage 0: Project launching}

Seventy people $(60 \%$ of the total Company's employees) participated in this stage of the project: the director, industrial manager, and 68 workers from the production sector (the ones in charge of allocating 
the rosettes, the ones that prepare the mixture, the others who pour out the mixture in the trays and the revisers), from the production support sector (expedition, maintenance) and from the administrative sector (sale, buyer, financing). $72.6 \%$ of the employees are men, $60.3 \%$ are in the day shift and $85.5 \%$ has less than 1 year of experience in the Company.

\subsection{Stage 1: Appraisal}

In MA, ergonomic appraisal is done with the direct workers' participation as well as the ergonomist's evaluation. Workers' demands are elicited following the Macroergonomic Design tool or MD [10,16], which proposes open interviews with a sample population (usually $30 \%$ ) to build questionnaires to be answered by the whole population. Forty-eight workers (from production, production support, administration and direction) participated in the interviews process, which were either done individually or in groups of up to five people according to workers' decision. The open interviews start with a single answer: "Tell me about your work". The answers (of a qualitative nature) are then evaluated and the ergonomic demand items (EDIs) that are more emphasized are used to build a questionnaire (of a quantitative nature), which also includes questions formulated by the ergonomists. The questions are organized in five constructs: environmental conditions, workstation, work organization, work content, the Company. Questions about what was the reason for the production waste and what to do to reduce it were also incorporated in the questionnaires The opinion of each worker with respect to each of the IDEs of the questionnaire is measured by means of a mark on a continuous $15 \mathrm{~cm}$ long assessment scale [13] therefore the intensity of each response varies between 0 (unsatisfied/ not at all) and 15 (satisfied/very much).

The questionnaires, responded by 72 workers (95\% of the population), showed good internal consistency by Cronbach's alpha statistics [17] (alpha= $0.71>0.55$ ) but did not show normality by Kolmgorov-Smirnov test. Therefore, the nonparametric Mann-Whitney U test was used to compare de results from the two shifts at a $95 \%$ confidence level.

The results were discussed with the Company's employees (second gate meeting) to make sure the results reflect the reality and also get more feedback for the next stage of diagnosis.

\subsection{Diagnosis}

In the diagnosis stage, the ergonomists evaluate the results obtained in the appraisal stage and, also based on the literature, develop alternative solutions to be discussed in a third gate meeting. Discussions of the diagnosis results with the managerial and nonmanagerial staff lead to the raise and implementation of proposals for improving the work conditions and reducing raw material waste.

\subsection{Proposal of solutions}

Proposal of solutions for the ergonomic problems were developed based on the diagnosis. The solutions for waste minimization were mainly based on the answers from the following questions formulated in the interviews and questionnaires:

1) What should be done with the wastes?

2) What should be done with the profits obtained by waste reduction?

The proposals were presented and discussed with 48 workers in groups of up to 5 people (third gate meeting).

\section{Results}

\subsection{Stage 1: Appraisal}

The Company is new (opened in 2002), employees 90 people (therefore being classified as small) in the manufacturing of 25,000 high heel pegs/day, in thermoplastic polyurethane (TPU). The production is done in two shifts, 46 workers in the day shift, from 05:50 AM to 03:50 PM, and 26 workers in the evening shift, from 04:00 PM to 12:40 AM.

The work consists of allocating very small rosettes (a metal piece that is the structure of the peg) in a mould tray, the number of rosettes varying according to the production order. The mould trays are heated for some time (not specified) in domestic ovens, and then taken from the oven, for temperature check. In the case it is below $55^{\circ} \mathrm{C}$, the mould tray is heated again with a blowtorch until the temperature reaches $70^{\circ} \mathrm{C}$. In the case it is over heated (i.e., the temperature is above $70^{\circ} \mathrm{C}$ ), the temperature is reduced with sprays of cold air.

While the mould trays' temperature is being adjusted, another worker prepares the amount of material according to the number of rosettes. Material is a mixture of moca, TPU and dye, prepared with no prescription. In the case the mixture is not correct (i.e., the color is different from the one requested by 
the buyer) it is thrown away. If it is correct, the mould tray is filled with it, and a ruler is used to eliminate the excess of material (that is also thrown away). The filled mould tray is heated with a blowtorch to remove eventual air bubbles. Then, the mould tray stays in a heater for 30 minutes, when it is removed for color checking. In the case it matches the order, the pegs are submitted to revision and cleaning by another worker. If the color does not match the specifications, or if there are bubbles, the pegs are thrown away. What cannot be cleaned in the Company is sent to ateliers (outsourcing familiar "companies") for new revision, and again, what cannot be repaired is thrown away.

Besides these wastes, there is also material waste when the order does not specify the exact number of pegs (or specifies the wrong number of pegs) to be produced, the over-production becoming waste.

The most frequent EDIs identified through the interviews were related to the high temperature in the sector; the fact that the production sector is not separated from the other sectors; they complained about people circulating in the sector because this disturb the work; the work organization of the type "one worker/one small task/one workstation"; lack of training; and lack of process prescription to be followed in order to produce the different components. Tables 1, 2 and 3 display, respectively, the results of the questionnaires in relation to the satisfaction with the IDEs related to the work environment/workstation, with the work organization, and the workers perception about the work content.

The workers in both shifts are unsatisfied with the temperature of the environment, the number and quality of booths for molding the TPU pegs and their temperature control system. All others EDIs are above the mean satisfaction level. There is statistic difference between the mean satisfaction with the uniform $(\mathrm{p}=0.013)$ and training $(\mathrm{p}=0.015)$, the evening shift being more satisfied with both EDIs. The higher satisfaction with the uniform can be explained by the fact that there is less heat in the evening, so the heavy and artificial uniform is not so uncomfortable.

They understand that their work involves high responsibility, is stimulating, dynamic and not monotonous, although repetitive. Although physical effort is low, mental effort is high and they feel very tired at the end of the journey. Workers do not feel pressured by the supervisors and managers and like the work, mainly because the Company is new and they foresee the growth of the Company they feel part of. Besides, having a job is very important, con- sidering the high level of lay-offs in mass in the shoe-manufacturing sector of Rio Grande do Sul. The sector is highly dependent on the oscillations of the international market, and Brazil is loosing market for the lower priced Chinese shoes. Mann-Whitney U test showed significant difference between the results from the two shifts, the evening shift considering the work more creative $(\mathrm{p}=0.013)$.

\section{Table 1}

Questionnaire's results of the EDIs related to the work Environment and Workstation. Scale varies from 0 (unsatisfied) to 15 (very satisfied)

\begin{tabular}{lccc}
\hline EDI & Day & Even & Mean \\
\hline Quality and number of booths & 6.19 & 5.51 & 5.94 \\
Temperature of the environment & 7.68 & 6.32 & 7.20 \\
Foreign people in the sector & 7.70 & 7.93 & 7.78 \\
Noise of the work environment & 7.82 & 8.32 & 8.00 \\
Temperature of the trays & 6.86 & 7.57 & 7.11 \\
Quality of the masks & 8.85 & 9.20 & 8.97 \\
Quality of the tools/equipment's & 9.46 & 8.66 & 9.18 \\
Quality of the uniform & 8.07 & 11.51 & 9.33 \\
Localization of the sector & 9.81 & 10.05 & 9.90 \\
Quality of the gloves & 11.01 & 8.31 & 10.02 \\
Illuminance of the environment & 12.05 & 9.97 & 11.32 \\
\hline
\end{tabular}

Table 2

Questionnaire's results of the EDIs related to the work organization. Scale varies from 0 (unsatisfied) to 15 (very satisfied)

\begin{tabular}{lccc}
\hline EDI & Day & Even & Mean \\
\hline Production planning & 9.03 & 9.06 & 9.04 \\
Number of different tasks performed & 10.21 & 9.14 & 9.82 \\
Training & 9.27 & 11.17 & 9.96 \\
Number of workers to do the work & 11.78 & 9.75 & 11.09 \\
\hline
\end{tabular}

Table 3

Questionnaire's results of the workers opinion about the work content. Scale varies from 0 (not at all) to 15 (very much)

\begin{tabular}{lccc}
\hline EDI & Day & Even & Mean \\
\hline Monotonous & 1.82 & 5.05 & 2.94 \\
Psychological pressure & 3.25 & 4.77 & 3.81 \\
Physical effort & 4.12 & 7.22 & 5.23 \\
Stressful & 5.33 & 5.54 & 5.41 \\
Limited & 5.53 & 9.01 & 6.76 \\
Mental effort & 7.79 & 8.55 & 8.06 \\
Crrative & 7.61 & 11.23 & 8.88 \\
Feels valued & 9.63 & 8.98 & 9.39 \\
Has autonomy & 9.84 & 9.29 & 9.64 \\
Dynamic & 9.72 & 9.53 & 9.65 \\
Estimulating & 9.74 & 9.80 & 9.76 \\
Repetitive & 9.89 & 11.89 & 10.62 \\
Likes the work & 12.72 & 13.19 & 12.89 \\
Responsibility & 12.52 & 13.95 & 13.04 \\
\hline
\end{tabular}


Table 4

Workers opinion about the factors that contribute to waste. Scale varies from 0 (not at all) to 15 (very much)

\begin{tabular}{lccc}
\hline EDI & Day & Even & Mean \\
\hline Order delay & 4.20 & 4.44 & 4.28 \\
Rosette & 4.12 & 5.94 & 4.77 \\
Quality of the cleanning cloths & 5.46 & 5.60 & 5.51 \\
Quality of the de-moulding & 4.94 & 6.75 & 5.61 \\
Material stocked at the expedition & 5.36 & 6.42 & 5.73 \\
Work done by the Ateliers & 7.87 & 7.97 & 7.91 \\
Temperature of the trays & 7.30 & 9.67 & 8.15 \\
Problems with the mixture color & 8.10 & 8.48 & 8.24 \\
Make the exact quantity of mixture & 8.82 & 7.88 & 8.48 \\
\hline
\end{tabular}

The results in Table 4 show that waste is due to lack of work prescription that leads to problems with the mixture and over-production. The workers are aware of the waste and are committed to reduce it. There is no statistic difference between shifts for the questions related to waste production.

\subsection{Stage 2: Diagnosis}

Physical environment needs improvement in relation to the temperature, which is hot in the summer and cold in the winter. According to Climatempo [6], Campo Bom is the hottest city in the state of Rio Grande do Sul, reaching $45^{\circ} \mathrm{C}$ in summer and $13^{\circ} \mathrm{C}$ in winter. Besides, the sector has extra heat from the ovens and heaters, the temperature in the sector being always above $25^{\circ} \mathrm{C}$ WBGT, what exceeds the limit of $25^{\circ} \mathrm{C}$ for continuous work as stipulated by Annex 3 of Brazilian norm NR15 [2]. Noise is a result of lack of layout organization and too many people circulating in the production sector.

Although the uniform was not evaluated negatively, attention should be paid to it because it is made of synthetic material that does not allow for proper transpiration, it is heavy, does not favor mobility and some tasks demand the use of a heavy leather apron. The workstations and equipments are old and inadequate.

There is waste of mixture because different sizes (height and diameter) of preparing cups are used depending on the amount of mixture, and the domestic ovens do not allow for standardized temperature of the molding trays. The layout does not favor the process flow, on the contrary, three are too many interruptions due to people bumping each other in a small space and too many people in the sector

The most important problem was the lack of knowledge about the process as a whole and the lack of prescriptions for the many different types of pegs they make. Without the prescriptions, the workers have to decide what to do without knowledge of the process, therefore being necessary to redue work by trial and error. Although the production process was more of a craft than mass production, work was organized according to Fordism, each worker acting in a small part of the process. Besides the repetitive nature of this type of production system, that fixes the worker in only one workstation, with no horizontal communication and no tacit knowledge share. With no learning from experience and a prescription, workers do not improve their performance, do not feel responsible for the production quality, and overall dissatisfaction and waste are the most common outputs.

The cost of a peg varies from U\$ 0,11 to 0,20 because it depends on the type of peg and, consequently, the amount of mixture used + the rosette. The cost of a peg weighting in average 2,5 grams is about U\$0,15 therefore $1 \mathrm{~kg}$ of waste costs U\$60 for the Company.

\section{Proposal of solutions}

\subsection{From the workers' point of view}

1) What should be done to minimize the wastes?

The workers proposed to set up the prescriptions for the pegs manufacturing on an electronic display, stating the amount of raw material needed for a given quantity of pegs, the type of cup to be used, and the oven temperature. They also suggested that the ovens should have temperature control, that color test should be made in a sample before manufacturing, and that the waste should be evaluated at each stage of the process in order to identify and solve the waste generation throughout the process.

2) What should be done with the profits obtained by waste reduction?

The workers know that waste is a cost, that the proposed solutions might minimize the wastes and understand that the profit should be shared with all employees and also be used to raise the salaries, to provide food baskets, to reward the prominent sector and to invest in the Company.

\subsection{From the ergonomists' point of view}

The unfavorable conditions of physical environment (high level of heat), workstation (old and/or inadequate equipments), work design (individual 
work, lack of prescriptions and training) and work well as issues related to the Company (lack of consideration to the workers quality of work and life) were the main reasons for the waste and overall dissatisfaction of the workers.

Although the Company understood that wastes are due to the workers lack of skills, they should not be blamed for it since there is no training and prescriptions and they do not know the whole process. Work design and workstations/equipments unfavorable conditions also add to make the work more difficult. The following were the propositions made by the ergonomists and the workers for work enhancement:

1) Change of layout for optimizing spatial distribution and the positioning of the various elements that conform the work space in order to enhance work and minimize four of the seven wastes related to layout: movement, waiting, over processing and transportation. The layout proposal was done with the collaboration of the workers who were invited to draw the "ideal" layout. The meetings happened once a week, for two months until they came to an agreement;

2) Improvement of the workstations and equipments;

3) Substitution of the domestic ovens by industrial ones. This was important for temperature standardization and elimination of the need to use the blowtorch, therefore avoiding accidents;

4) Increase of the number and quality of booths to reduce waiting time for an available one. Booths with better exhausting system improve air quality;

5) Improvement of the physical environment, mainly temperature and ventilation;

6) Change of the uniform, substituting the synthetic pants and shirts for cotton ones.

7) Work design improvement, by changing the traditional system to the socio-technical (multifunctional teamwork) one, incorporation of training, prescriptions for production of the different pegs, and making explicit the real work, in a notebook, to be shared by all workers.

8) In relation to waste reduction, Table 5 presents a summary of the problems as classified according to [20] to which was added an eight waste, the ergonomic one, and the solutions proposed. The Company did not know the amount of waste generated by each part of the process, therefore, another suggestion was the evaluation of the origin and type of waste (i.e., excess use of material, wrong mixture, defective pegs, etc) in order to better improve the system.

Table 6 shows the wastes generated in production and in the samples for months May and December content (high level of repetitiveness of the tasks) as 2009. It can be assumed that there is no difference in the wastes generated by the shifts and also no difference in the waste generated in the samples. However, the percentage of production waste is higher in May (when the project started) in comparison with December, when production waste reduced from $26.6 \%$ to $19.3 \%$ in the day shift, and from $27.2 \%$ to $16.5 \%$ in the evening shift after the improvements made in the layout, in the workstations/equipment, and the new ovens. Besides the savings of U\$7,239/month (a $31.5 \%$ saving) with waste reduction, the workers commented that they got more satisfied with the work after the improvements implemented until December.

\section{Conclusions}

This article presented an ergonomic intervention in a small TPU high heels pegs manufacturing Company situated in the state of Rio Grande do Sul, Brazil. The demand was originated by the Company, worried about the high cost of the production waste, which it understood was responsibility of the unskilled workforce.

Using participative ergonomics, the problems were identified and solutions were proposed and implemented. Quality of the environment and workstation was improved, basic rules for the use of raw material and production of the components were developed and a capacitation course was offered for the staff. The traditional Ford work design model was replaced by the socio-technical (multifunctional teamwork) one which gave more autonomy and responsibility for the workers to control the quality of both process and products. At the end of the project, the workers got more involved in their work, got the feeling of being an important part of the company and the waste decreased generating savings of about $31.5 \%$. The profit was shared among all Company's employees, as proposed by the workers. It is expected that both work conditions and waste reduction improve after all proposed solutions are implemented.

The study showed that workers understand their jobs and are able to propose solutions that increase the quality of work, reduce costs and increase productivity. Companies should value their workers in order to improve the overall working conditions, which lead to better quality of life and production outcomes. 
Table 5

Summary of the problems and the proposed solutions for minimizing negative ergonomic outcomes and production wastes

\begin{tabular}{lll}
\hline Type of waste & Proposal of solutions \\
\hline $\mathbf{1}$ & Over-production & $\begin{array}{l}\text { With the production order, a label is } \\
\text { attached to the mould trays in order to } \\
\text { inform the peg model and quantity to } \\
\text { be produced }\end{array}$ \\
& $\begin{array}{l}\text { Transportation } \\
\text { Change in layout }\end{array}$
\end{tabular}

\section{Over-processing}

5 Motion

6 Inventory

$7 \quad$ Waiting

8 Ergonomics (not mentioned by Ohno, 1988)
Substitution of domestic ovens for industrial ones

More cleaning booths

Better exhausts

Mixture prescription for color standardization

Standardization of mould trays temperature to avoid bubbles

Substitution of the traditional work design by the socio-technical model (multifunctional teamwork)

Change in layout and work design

With the production order, a label is attached to the mould trays in order to inform the rosettes model and quantity to be used

Substitution of domestic ovens for industrial ones

More cleaning booths

Production synchronization. Production started in the morning and after lunch with 30 minutes delay due to the need to wait for the pegs in the heater Substitution of the traditional work design by the socio-technical model (multifunctional teamwork)

Reduce production flaws. If the mixture color is wrong, it is necessary to wait up to 20 minutes, with no other task to be carried out

Reduce the high environmental temperature, which generates fatigue and adds to low productivity and lack of attention

Inappropriate layout generates unnecessary movements, physical load and fatigue

Eliminate the adoption of awkward postures which generate fatigue and WMSD

\section{Improvements}

Production follows the exact specification of quantity of pegs ordered by the client

Change in layout reduced unnecessary movements and ended the bumps that lead to materials and equipments dropping as well as accidents

mould trays Temperature were standardized, eliminating over or under heating. The elimination of torch eliminated a source of accidents

With the increase in the number of available booths, cleaning could be made with no bumps and waiting.

With better exhausts, there is no need to change the masks since emissions are efficiently collected and launched

The prescriptions detail the amount of material, size and diameter of the mixture cups

The substitution of domestic ovens for industrial ones made it possible to standardize the mixture temperature, eliminating the bubbles In a socio-technical production system workers act in the whole process and are responsible for the quality of both production and process. Therefore, defects are deduced.

The work being done in teams in a better layout reduced unnecessary motion, waste of time, use of material and defective products Because only the exact number of pegs, as specified in the order, is produced, there is no increase in the inventory

Standardization of mould trays temperature, avoided the waiting time for cooling and heating mould trays

The increase in the number of booths reduced the waiting time for having available booths

Synchronization was done by letting part of the workers start 40 minutes earlier in order to allow for the other workers have products to produce when journey starts.

When work is done in teams of multifunctional workers responsible for all tasks of the process there is no need for one worker to wait for the other to finish a previous task in order to start his/her task

The prescriptions avoid producing the wrong color

The opening of windows in the pavilion and installation of air conditioners brought temperature to comfort level

Change in layout reduced the unnecessary movements, physical load and fatigue

Improvement in the workstations made work easier, the sitting and standing position reducing the risks 
Substitution of the traditional work design by the socio-technical model (multifunctional teamwork)
The socio-technical model allows the multifunctional workers performing in teams to share knowledge, be partners and get more involved and committed to the work. This increases satisfaction and reduces WMSD, illnesses and accidents risks

Table 6

Generation of waste in the samples and production of pegs in May and December 2009. Values are in kg; \% relates to percentage of waste in relation to the total production.

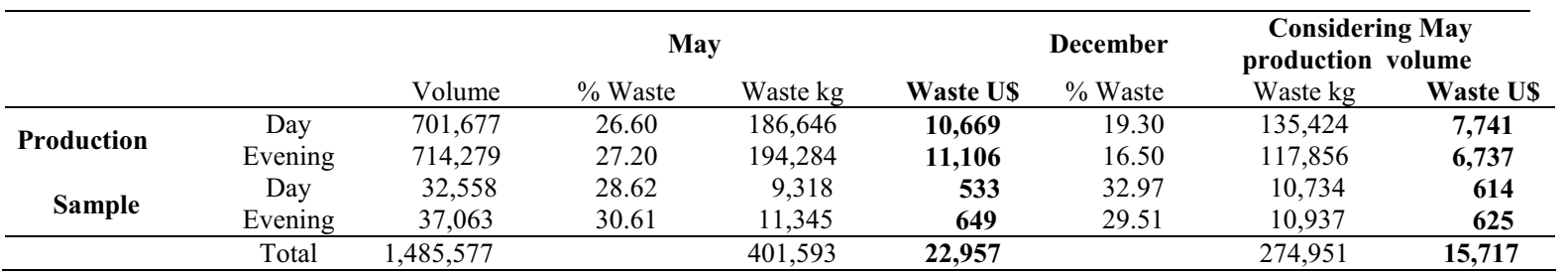

[9] European Union, Consolidated versions of the Treaty on European Union and the Treaty on the Functioning of the European Union, 2008. http://eurlex.europa.eu/LexUriServ/LexUriServ.do?uri=OJ:C:2008:115: 0001:01:EN:HTML Acessed August 10, 2011.

\section{Acknowledgments}

This research was partly funded by the Brazilian Federal Agency for the Support and Evaluation of Graduate Education (CAPES). The authors are grateful to the Company and all workers for their participation, support and interest in the project.

\section{References}

[1] A. J. De Oliveira, Caracterização Mecânica e Reológica de Polipropileno Reciclado para a Indústria Automotiva. Dissertação de mestrado, Engenharia Mecânica PUC/PR. 2006.

[2] Brasil, Ministério do Trabalho e Emprego. NR15 Anexo 3, 1978. Publicação D.O.U. Portaria GM n. ${ }^{\circ} 3.214$, de 08 de junho de 1978.

[3] Brasil, Ministério do Meio Ambiente Politica Nacional do Meio Ambiente, lei 6938,1981 http://www.mma.gov.br/port/conama/legiabre.cfm?codlegi=3 13 Accessed August 10, 2011.

[4] Brundtland Commission 1987, Our Common Future. Chapter 8: Industry: Producing More with Less, From A/42/427, Our Common Future: Report of the World Commission on Environment and Development. http://www.un-documents.net/ocf08.htm\#I, Acessed August 18, 2011.

[5] C. Berggren, Alternatives to lean production: work organization in the Swedish auto industry, Ithaca, NY, ILR Press, 1992

[6] Climatempo. Previsão do tempo/Meteorologia e Notícias em tempo real. http://www.climatempo.com.br/noticias/ Acessed January, 10, 2011.

[7] C. Dejours, Travail: usure mentale, Paris, Le Centurion, 1980.

[8] Environmental Protection Agency - EPA, 1976, Resource Conservation and Recovery Act of 1976. http://uwmc.uwc.edu/geography/350/RCRA.htm Acessed August 10, 2011.
[10]F.S. Fogliatto and L. B. de M. Guimarães, Design macroergonômico: uma proposta metodológica para projetos de produto. Produto \& Produção, Porto Alegre, 3 (3) (1999), pp. $1-15$.

[11]G. Friedman, Le travail en miettes: spécialisation et loisirs, Paris, Gallimard, 1967.

[12]H. Braverman, Labor and monopoly capital: the degradation of work in the twentieth century, New York, Monthly Review Press, 1998.

[13]H. Stone, J. Sidel, S. Oliver, A. Woolsey and R.C. Singleton, Sensory evaluation by quantitative descriptive analysis, Food Technology, 28 (1) (1974), pp. 24-34.

[14] K. Nishiyama and J. V. Johnson, Karoshi -Death from overwork: Occupational health consequences of the Japanese production management (Sixth Draft for International Journal of Health Services), Report on Karoshi from the Job Stress Network website of the Center for Social Epidemiology (February 4, 1997). http://www.workhealth.org/whatsnew/lpkarosh.html Accessed August 18, 2011.

[15]L.B. de M. Guimarães, Ergonomic approach: the macroergonomic method, in: L.B. de M. Guimarães (Org.) Ergonomics in Production, Porto Alegre, FEENG, fourth ed.v. 1. chap. 1.1., 1999.

[16]L.B. de M. Guimarães and F.S. Fogliatto, Macroergonomic Design: a new methodology for ergonomic product design. in: IEA 2000 (International Ergonomics Association Conference), San Diego (California), Proceedings of IEA 2000 (International Ergonomics Association Conference) v. 2., pp. 328-328, 2000.

[17]L. J. Cronbach, Coefficient alpha and the internal structure of tests, Revista Psychometrika, 16 (1951), pp.297-334.

[18] S. Omi, M. Morimoto and S. Suda, An outline of activities by the Committee of Design for Environment (DfE), Japan, 1994-2001, in: International Symposium on Environmentally Conscious Design and Inverse Manufacturing (Ecodesign'01), 2., 2001, Tokyo. Washington, IEEE, 848, 2001.

[19] S. Shingo, The Toyota production system, Tokyo: Japan Management Association, 1981. 
[20]T. Ohno, Toyota production system: beyond large-scale production, Cambridge, Mass.: Productivity Press, 1988.

[21] United Nations Conference on the Human Environment, 1972, Report of the United Nations Environment Programme Stock-

holm

http://www.unep.org/Documents.Multilingual/Default.asp?do cumentid=97 Accessed August 10, 2011.
[22] United Nations Conference on Environment and Development, 1992

http://www.un.org/documents/ga/conf151/aconf151261 annex1.htm Accessed August 10, 2011.

[23] World Commission on Environment and Development, 1983 http://www.un.org/documents/ga/res/42/ares42-187.htm Accessed August 10, 2011. 